\title{
The System of State Programming and Project Planning as a Way to Minimize Territorial Differences in the Social and Economic Development in the Territorial Entities of the Russian Federation
}

\begin{abstract}
Natalya Pasmurtseva*
Ural State University of Economics, Yekaterinburg, Russian Federation

"Corresponding author. Email:pnn-kufeu@yandex.ru

ABSTRACT

The modern state economic policy of the Russian Federation is aimed at reducing social and economic inequalities and developing regions and territories. An important role in solving this issue is played by state programs and national projects implemented within the framework of the state strategic planning system, one of the elements of which is state programming and project planning. The current research contains a model of today's system of state programming and project planning, the formation of which is necessary to ensure the national economic system strategic development. The author analyzes a number of indicators stated by the 2018"May decrees" of the President of the Russian Federation, that are aimed at reducing territorial social and economic differences, and defines problems and risks arising in the process of state programs and national projects implementation around the Russian Federation.
\end{abstract}

Keywords: system of state programming and project planning, territorial social and economic differences, state programs and national projects, territorial entities of the Russian Federation.

\section{INTRODUCTION}

One of the key areas of Russia's strategic development is to solve the problem of territorial differences in the social and economic development in the territorial entities of the Russian Federation. This issue is of paramount importance not only because of the need to provide equal opportunities to all citizens of the Russian Federation and improve their well-being and quality of life, the solution of this problem is also connected to ensuring national economic security. Thus, the Spatial Development Strategy of the Russian Federation for 2025 focuses on the need to "... reduce regional differences in the population level and quality of life, and accelerate economic growth and technological development" [1].

"A contrast between significant improvement in the conditions and quality of life in some regions of Russian Federation against the deterioration in others inevitably leads to migration and brain drain from the territories in the state of economic doldrums" [2], which increases socio-economic instability, reduces the competitiveness and investment attractiveness of such territories.

The problem of territorial differences is determined, first of all, by the differentiation of such indicators as: GRP (including per capita), the regions' own budget revenues, as well as the amount of federal financial assistance and of funds redistributed through the federal budget

Thus, according to Federal State Statistics Service [3], in 2019, the maximum GRP per capita in the Yamalo-Nenets Autonomous Region was 50 times higher than its minimum value in the Republic of Ingushetia. A comparative analysis of the average per capita income in 2019 also demonstrates a significant difference, reaching a value of 83,385 rubles in the Chukotka Autonomous Region compared with the minimum average per capita income in the Republic of Tyva, which amounted to 16,583 rubles and is 5 times lower than its maximum in Russia. 
To solve the problem of territorial socio-economic differences Russian Federation uses various means aimed at:

- forming an effective system of interaction between government, business and the population in order to solve territorial problems, such as creating public-private partnerships, encouraging the population to participate in the local national projects and state programs, for example selection of territories, online voting for the public spaces improvement on special sites within the "Housing and Urban Environment" national project;

- providing state assistance for people moving to developing regions and promoting the growth in population mobility (e.g. the Far Eastern Hectare program, the state program "Integrated Development of Rural Areas", the purpose of which is to provide housing for those living in rural areas);

- the development of the labor market and social and transport infrastructure in rural areas;

- the "Healthcare Development" state program (from 2012 to 2019 the Zemsky Doctor project was implemented), which allows doctors who have moved to remote and hard-to-reach territories to receive large lump-sum payments;

- the creation of special economic zones (SEZs), which are formed for the development of certain sectors of the economy and attracting investment, for example: Baikal Harbor SEZ, which activities are aimed at preserving the unique Lake Baikal and developing tourism in this territory;

- building highly technical and innovative SEZs, to implement venture projects, including the large ones on the development and production of hightech products;

- levelling up the quality and quantity of public services provided to the population.

In the process of implementing the 2018 "May decrees" of the President of the Russian Federation a special place is given to national projects, which, being the instruments of state strategic programming and design, contribute to reducing territorial socio-economic differences, as they are focused on improving the the population level and quality of life in the whole country, regardless of the resident region, and provide all citizens with equal opportunities. Similar opportunities are also provided by socio-economic state programs, the development and implementation of which has been actively carried out in the Russian Federation since the 2010s. In 2020 the implementation of state programs was accounted to take about $75 \%$ of all state budget expenditures, and it is planned to allocate 25.7 trillion rubles to 12 national projects, which are planned to be incorporated by 2024 [4].4
Thus, state strategic design and programming is an important way of reducing territorial socio-economic differentiation, and the following research might have a high relevance to the the national economy strategic development and security.

The purpose of this scientific research is:

1) to assess today's system of state programming and design in terms of strategic development and national economic security;

2) to analyze the indicators defined by the 2018 "May decrees" of the President of the Russian Federation, that are aimed at reducing territorial socio-economic differences;

3) to define problems and threats that may show in the in the process of $\mathrm{s}$ achieving their target indicators and results via the programs and national projects implementation.

\section{MATERIALS AND METHODS}

The system of state programming and project planning in Russian Federation is a set of state programs and national projects implemented by public authorities in order to improve the population's welfare and life quality of life and to ensure strategic national security.

The system of state programming and project planning is regulated by such federal statutory instruments as: Federal Law No. 172 "On Strategic Planning in the Russian Federation" (June 28, 2014), Decree of the Government of the Russian Federation No. 786 "On the Management System of State Programs of the Russian Federation" dated May 26, 2021, Regulation on the Organization of Project Activities in the Government of the Russian Federation, approved by Decree of the Government of the Russian Federation No. 1288 dated October 31, 2018.

The state program is a "strategic planning document containing a set of planned activities (or results), interrelated in terms of tasks, deadlines, performers and resources, and state policy instruments that ensure the achievement of priority tasks and goals of state policy in the relevant areas of economic and social development and national security of the Russian Federation, including those aimed at achieving the national development goals of the Russian Federation, defined by the Decree of the Russian Federation No. 474 "On the National Development Goals of the Russian Federation for the period up to 2030"dated July 21, 2030 [5].

Today in the Russian Federation 46 state programs have been developed and are being implemented in five areas focused on creating an effective system of public administration, formimg a high level of quality of life of citizens, as well as modernization of the economy, 
ensuring national security and balanced development of the regions of the Russian Federation.

The "Regulations on the organization of project activities in the Government of the Russian Federation" define the project as "a set of interrelated measures aimed at obtaining unique results under time and resource limits" [6]. They also tell the specifics of federal, regional and departmental projects.

In general, the project as a tool of state strategic planning has a strictly defined goal related to the creation or development of a specific thing. Unlike the program, which may have a long implementation period, the project can be paused and resumed and has a clear deadline set.

Currently, 12 national projects have been developed, approved and are being implemented in the Russian Federation. They are aimed at improving the level and quality of life of every resident in every subject of the Russian Federation. Thus, the method of programming and developing the national economy is widely used in the Russian Federation, and it is an integral element of the system of state programming and design.

In the author's opinion, the model of the system of state programming and project includes the following stages.

1. Identify problems and risks existing in socially significant spheres, some independent sectors of the national economy, regions and territories of the Russian Federation that hinder the growth in the population level and quality of life.

As a rule, the stage of identifying problems and risks includes an assessment of the current situation in a certain area, field, region or territory, as well as defining sore points, usually at three levels: very serious; quite serious; serious, but not requiring an on-the-spot solution

2. Defining the directions for the development of a sphere or region within the framework of a state program or a national project. Thus, federal projects aimed at developing a narrower path for a particular socially significant sphere of the state are implemented within the framework of national projects. For example, within the framework of the "Health service" national project there is a federal project aimed at the development of children's health service.

3. Assessing the resources potential required for the implementation of state programs and national projects within the system of state programming and project planning. At this stage, first of all, of the financial resources of the Russian Federation necessary for the implementation of a state program or a national project are being analysed. For example, in 2021, "... it is planned to spend more than 4.2 trillion rubles from all sectors of the Russian Federation the budget system on education (3.6\% of GDP), and more than 4.0 trillion rubles on Health System (3.4\% OF GDP)" [7]. At the same time, the budget expenditures on the "Health Service" national project in 2019-2024 will be up to 1.7 trillion. rubles, and for the "Education" national project 784 billion rubles, "while average expenditures on all 13 national projects make only $12 \%$ of all federal budget expenditures over a three-year period" [8].

4. Developing the state program or national project, settling and approving it according to the current legislation of the Russian Federation. This stage includes the development of a state program or a national project; defining goals, targets and costs; stating the main directions for the field or region development. Besides, the stage includes setting the state authorities and specific officials responsible for the implementation, and the deadlines for the program or project implementation.

5. The stage of implementation of the state program. It involves certain actions together with defining their connection with specific tasks of the program. For a national project they set out specific results that should be achieved during its implementation.

6. Control and monitoring of the state program or national project implementation, aimed at the diagnosis of its effectiveness and at the correct deadlines for adjustment arrangements if necessary.

\section{RESULTS AND DISCUSSIONS}

State programs and projects developed and implemented according to the "May" decrees of the President of the Russian Federation make it possible to improve the population quality of life in all territorial entities of the Russian Federation, regardless of their location and natural, economic and human potential.

In this study, the author has analyzed the indexes of the Russian Federation socio-economic development, that are necessary for national projects monitoring both in federal districts and in the Russian Federation itself, for the period of 2018-2020. Special attention has been given to indexes for such national projects as "Demography", "Health Service", "Housing and urban environment", as well as federal projects included into them, like "Financial support for families with new children", Supporting women's employment and forming conditions for preschool education for children under three years old", "Senior citizens"..

Thus, according to the Federal State Statistics Service [3], for the period of 2019-2020 there is a wavering positive trend in second children birth-rate, connected to the absence of its decrease in most federal districts and territorial entities of the Russian Federation. This proves equal opportunities to receive financial support for families with new-born children regardless their place of residence (Figure 1). 


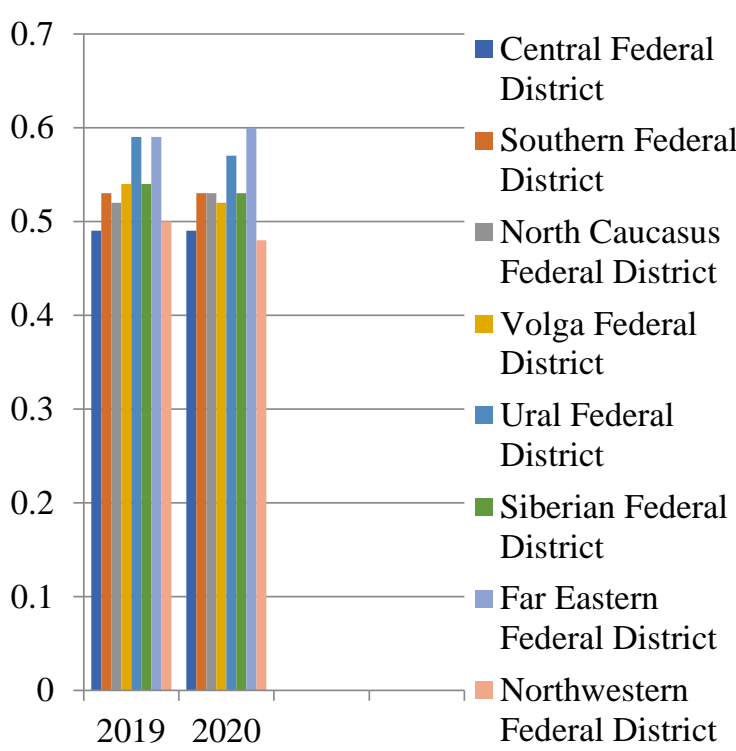

Figure 1 Dynamics for aggregate second children birth rate in the Russian Federation for several federal districts for the period of 2019-2020.

Besides, in most federal districts the studied index is within the range of $0.5-0.6$, which indicates the number of second children births per woman, and also shows the even number of births across the regions of the Russian Federation. On the other hand, there was a fairly steady growth in the number of third and subsequent children in 2019-2020 (Figure 2), which is also largely due to such means of state support as maternal (family) capital, opportunities to receive child benefits, additional state benefits related to having many children, which are implemented in all territorial entity of the Russian Federation and provide all citizens with equal opportunities. The largest increase in this number is demonstrated by the Far Eastern (9.8\%), Ural (7.9\%) and North Caucasian $(4.4 \%)$ federal districts.

The number of children under three years entering state and municipal Early Childhood Education organizations shows an increase in 2019 compared to 2018 (Figure 3), which demonstrates an increase in the availability of preschool education in most territorial entities of the Russian Federation. The largest increase in the number of pupils under the age of three attending these organizations in the studied period was $6 \%, 3 \%$ and $3 \%$ in the North Caucasus, Ural and Volga Federal Districts respectively.

According to Federal State Statistics Service [3], the number of housing constructions estimated within the "Housing and Urban Environment" national project had improved in 2018-2020, both in the Russian Federation and in federal districts and most entities of the Russian Federation. A growing trend is seen in all federal districts, while the highest numbers of housing construction in 2020 (compared to 2018) are demonstrated by: Southern $(20.9 \%)$, Volga $(6.7 \%)$ and Ural $(16.7 \%)$ federal districts.

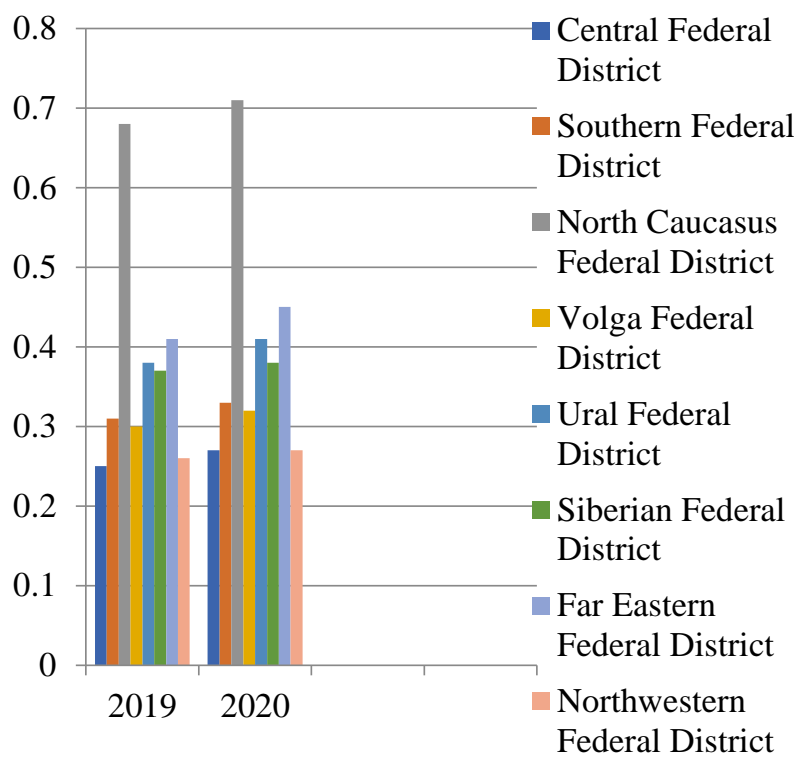

Figure 2 The number of third and subsequent children in Russian Federation for several federal districts for the period of 2019-2020. (Drawn by the author according to Federal State Statistics Service data).

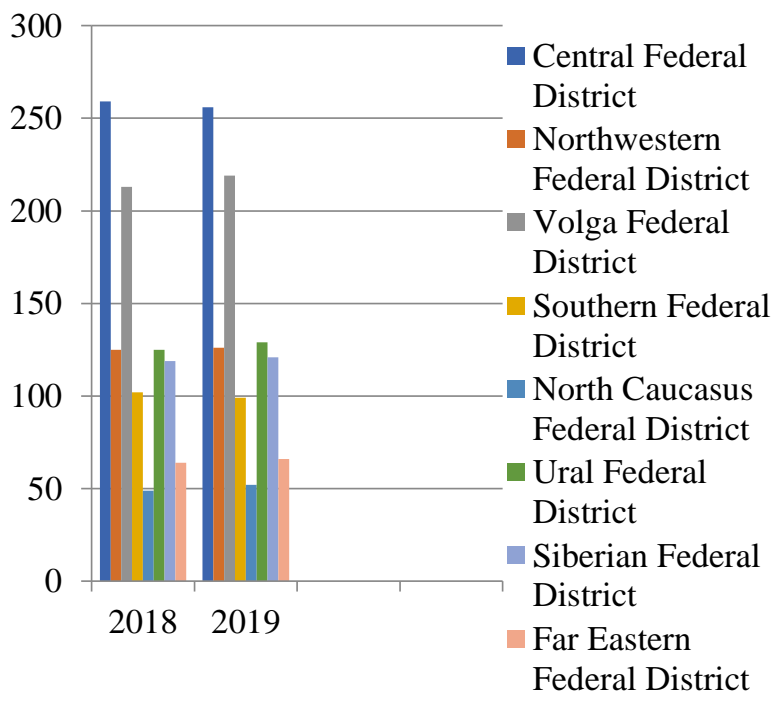

Figure 3 The number of children under three years entering state and municipal Early Childhood Education organizations for the period of 2019-2020, thousand people. (Drawn by the author according to Federal State Statistics Service data).

However, some of the national projects show lower key indexes compared to the past ones. The most important national project, "Demography", shows a decline in a number of points. For example, the number of citizens with a healthy lifestyle has a negative growth in 2020 compared to 2019 in all federal districts of the 
Russian Federation. A significant decrease here is demonstrated by the Central (31.5\%), Volga (43.2\%) and Southern Federal Districts (29.7\%).

There is a decrease in the figure of healthy life expectancy by more than one year: from 60.3 years in 2019 to 58.9 years in 2020 in Russia. A similar trend is noticed in all federal districts and most of the entities of the Russian Federation, which is primarily due to the COVID-19 pandemic, and as a result, the overload of the health system and the lack of medical services and promotion of protective measures and a healthy lifestyle.

However, despite the existing negative dynamics in a number of targets and indicators for the implementation of state programs and national projects, tofay's system of state programming and project planning can be considered quite effective and contributes to reducing gaps in the social and economic development of regions in the Russian Federation. According to the Ministry of Economic Development of the Russian Federation, the implementation monitoring of 41 state programs out of 45 showed the average efficiency of $80.3 \%$ in the first half of 2021 , which is $1.8 \%$ higher than in the third quarter of 2020. At the same time, 13 state programs have high efficiency (more than 92\%); 13 state programs also have aboveaverage efficiency (from 82 to $92 \%$ ) [9].

Besides, there are projects and programs aimed at improving the living standards and well-beig of citizens living in certain territories of the Russian Federation, such as the Far East, Kaliningrad, some rural areas. At present, state programs on the social and economic development of the Republic of Crimea and the city of Sevastopol, the Kuril Islands, the Republic of Karelia are being implemented, as well as the program for the protection of Lake Baikal and the development of the Baikal natural territory, and the "Far Eastern Hectare" state program.

\section{CONCLUSION}

Over the past few years, the Russian Federation has been actively forming and developing a regulatory and legal framework standardizing the system of system of state programming and project planning, which makes it possible to reduce social and economic territorial differences in the Russian Federation by allocating financial resources to state programs and national projects in the regions in order to improve the living standards of the population throughout Russia.

Since 2014, the budgets of the treasury system of the Russian Federation "are formed on the basis of state (municipal) programs" [10]. The program-target approach and professional project management is considered an effective development tool and a method to effectively reach strategic aims and objectives.
However, in the existing system there are a number of problems that can obstruct the effective implementation of state programs and national projects in the Russian Federation.

1. Despite the growing number of state programs and national projects in the Russian Federation, in general, the system itself has its drawbacks and it would be incorrect to consider it fully effective. For example, the implementation monitoring of state programs taken by the Ministry of Economic Development of the Russian Federation showed that 9 programs demonstrate below-average effectiveness, and another 6 programs were recognized as low-effective (efficiency rate was below $61 \%$ ) [9, 12].

2. In the system of state programming and project planning dome state programs are duplicated by national and federal projects. For example, federal projects aimed at reducing cardiovascular and oncological diseases are included both in "Health System Development" state program for 2018-2025 and into "Health System" national project. Similar matchings take place in the "Demography" national project where the "Public health improvement" federal project within the framework of "Demography" national project duplicates the "Forming public motivation to a healthy lifestyle, including healthy eating and giving up bad habits" federal project within the framework of the "Development of healthcare" state program, and so оп.д.

3. Currently implemented state programs and national projects often do not consider cultural peculiarities and imbalances in the social and economic development of Russian regions. For example, when calculating indicators for the "Demography" project, it is necessary to take into account that in the Russian Federation there are territorial entities with a traditionally high birth rate, and vice versa..

4. State programs and projects do not really consider unforeseen external risks of decline in the overall macroeconomic system, both in the Russian Federation and in the world; changes in federal legislation; contradictions in the requirements for regional social policy imposed on the entities of the Russian Federation by the Government of the country.

5. There are also internal risks, which include organizational difficulties due to state programs implementation management mistakes, or to an entity of the Russian Federation not fulfilling its expenditure commitments on priority expenses, etc. For instance, the state programs implementation monitoring for the first half of 2021 showed that there is a large number of unfulfilled milestone activities (for 34 programs), the onset of which exceeds the planned one by more than a month. Hence, it is concluded that there are some 
drawbacks in the process of planning and appointing the responsible executors [9].

6. Despite the population's high level of awareness about the state programs and national projects implementation, the interaction between the government and the population at the stage of developing and decision-making on certain projects implementation activities remains minimal. As a result, the developed strategic documents do not always correspond to the people's ideas on how their well-being will be finally improved through the implementation of these programs and projects $[11,13]$.

In modern realities, the development of regions is one of the priority goals of Russia's economic policy. To solve the problem of regional inequality and territorial development, the government is actively implementing measures aimed at:

- stabilizing the population in all territorial entities of the Russian Federation,

- improving the urban environment comfort level,

- developing social and transport infrastructure,

- improving the environment,

- increasing the level of entrepreneurial activity,

- improving the quality of medical care.

At the same time, the main means of solving the above issues are national projects and state programs, the single priority of which is to improve the population level of life throughout the Russian Federation, which in turn will contribute to the social and economic development of both individual regions and territories, and the national economy as a whole.

\section{REFERENCES}

[1] The strategy of spatial development of the Russian Federation for the period up to 2025, approved by the order of the Government of the Russian Federation dated February 13, 2019 No. 207-r. https://www.economy.gov.ru/material/file/a3d075a a813dc01f981d9e7fcb97265f/130219_207-p.pdf.

[2] M. S. Syupova, Differentiation of socio-economic development of municipalities as a threat to the economic security of the region, Power and management in the East of Russia, 1(94) (2021) pp. 70-79.

[3] Federal State Statistics Service of the Russian Federation. https://rosstat.gov.ru/folder/53175.

[4] S. S. Golubev, O. M. Elfimov, Improving the efficiency of the implementation of national projects and government programs based on the implementation of project management principles, On the guard of the economy, 3(10) (2019) pp. 1624.
[5] Decree of the Government of the Russian Federation of May 26, 2021 No. 786 "On the management system of state programs of the Russian Federation." http://government.ru/docs/all/134475.

[6] Regulation on the organization of project activities in the Government of the Russian Federation, approved. Decree of the Government of the Russian Federation of October 31, 2018 No. 1288 (as amended by the Decree of the Government of the Russian Federation of 10.07.2020 No. 1019). http://government.ru/docs/34523/.

[7] A. B. Berendeeva, N. S. Rychikhina, O. O. Korobova, Approaches to assessing the effectiveness of the implementation of social projects of the state in the regions of Russia // Modern science-intensive technologies. Regional application, 1(65) (2021) pp. 17-29.

[8] R. S. Danilov, P. A. Kartysheva, Influence of national projects on the structure of expenditures of the budgetary system of the Russian Federation, State Service, 5(127) (2020) pp. 19-25.

[9] Monitoring of the implementation of state programs of the Russian Federation in the first quarter of 2021 by the Ministry of Economic Development of the Russian Federation. https://www.economy.gov.ru/material/file/999cf345 122f4bc1a489ba544eb9fdc0/monitoring_realizacii_ gosprogramm_I-II_2021.pdf.

[10] M. V. Chumakov, A. A. Elizarova, A. B. Berendeeva, Analysis of efficiency and risks in the implementation of government programs, projects, strategies in the regions of Russia, Modern scienceintensive technologies. Regional application, 2(66) (2021) pp. 65-75.

[11] N. N. Pasmurtseva, Formation of the system of state strategic management: model and implementation problems, Moscow economic journal, 8 (2020) pp. 573-583.

[12] N. Pasmurtseva, The Knowledge Potential in the System of Strategic Management of the Innovative Development of an Enterprise, Industry Competitiveness: Digitalization, Management, and Integration. 1 (2020) pp. 411-417.

[13] N. Pasmurtseva, Innovative activity of the Russian industry in the context of the transition to the digital economy: trends, threats, and opportunities, First Conference on Sustainable Development: Industrial Future of Territories (IFT 2020). Yekaterinburg, Russia, 2020. 